\title{
Minor tumor infiltrating B cells opened a door to reveal and eliminate cancer initiating cells in metastatic melanomas
}

\author{
Beatrix Kotlan ${ }^{1,5^{*}}$, Gabriella Liszkay², Gyorgy Naszados ${ }^{3}$, Judit Olasz ${ }^{4}$, Szabolcs Horvath ${ }^{5}$, Vanda Plotar ${ }^{5}$, \\ Andras Szollar ${ }^{6}$, Istvan Nagy Vamosi ${ }^{6}$, Akos Savolt ${ }^{6}$, Laszlo Toth ${ }^{6}$, Orsolya Csuka ${ }^{4}$, Maria Godeny ${ }^{3}$, Miklos Kasler ${ }^{7}$, \\ Francesco M Marincola ${ }^{8}$
}

From Updates on Immunotherapy of Cancer and Immunoscore Symposium, part of the Sidra Symposia Series, held in partnership with the Society for Immunotherapy of Cancer

Doha, Qatar. 22-23 January 2014

\section{Background}

The theory and investigations on cancer stem cells (CSCs) have received growing attention, as these cells are responsible for the failure of cancer therapeutic strategies and the return of cancer.

\section{Materials and methods}

A complex tumorimmunological study on primary and metastatic cancerous tissue biopsies and peripheral blood of patients with malignant melanomas $(n=153)$ has been performed with ethical permission (ETT TUKEB 16462- 02/2010) and patients' formal consent.

\section{Results}

We developed a methodology to select cancer initiating cells from fresh cancer cell cultures of malignant melanomas. Characteristic cell growth pattern, spheroid forming, CSC markers, like CD133, Nestin, ABCB5, CD20 and unique GD3 ganglioside expression were defined by immunofluorescence assay. Additionally tumor infiltrating B cells' sialilated glycosphingolipid binding was defined by antibody phage display and immunglobulin repertoire analysis. Real Time PCR gene expression studies were done to reveal molecular parameters of regulatory mechanisms.

\section{Conclusion}

We provide here a novel strategy to detect cancer initiating cells in metastatic melanomas by double labeling with anti CD20 antibodies and sialilated glycosphingolipid antigen specific immunglobulins. With antibody engineering present findings might be turned into a novel cancer therapeutic approach targeting cancer stem cells.

\section{Acknowledgements}

Harry J. Lloyd Charitable Trust Melanoma Research Award/ 2010.

\section{Authors' details}

${ }^{1}$ Molecular Immunology and Toxicology, National Institute of Oncology, Budapest, Hungary. ${ }^{2}$ Oncodermatology, National Institute of Oncology, Budapest, Hungary. ${ }^{3}$ Radiological Diagnostics, National Institute of Oncology, Budapest, Hungary. ${ }^{4}$ Pathogenetics, National Institute of Oncology, Budapest, Hungary. ${ }^{5}$ Surgical and Molecular Tumorpathology, National Institute of Oncology, Budapest, Hungary. ${ }^{6}$ Oncosurgery, National Institute of Oncology, Budapest, Hungary. ${ }^{7}$ Board of Directors, National Institute of Oncology, Budapest, Hungary. ${ }^{8}$ Research, Sidra Medical and Research Center, Doha, Qatar.

Published: 24 February 2014

\footnotetext{
doi:10.1186/2051-1426-2-S1-P4
}

Cite this article as: Kotlan et al:: Minor tumor infiltrating B cells opened a door to reveal and eliminate cancer initiating cells in metastatic melanomas. Journal for ImmunoTherapy of Cancer 2014 2(Suppl 1):P4.

Molecular Immunology and Toxicology, National Institute of Oncology,

Budapest, Hungary

Full list of author information is available at the end of the article

C 2014 Kotlan et al; licensee BioMed Central Ltd. This is an Open Access article distributed under the terms of the Creative Commons Attribution License (http://creativecommons.org/licenses/by/2.0), which permits unrestricted use, distribution, and reproduction in any medium, provided the original work is properly cited. 